\title{
Research on English Literature Education Practice and Dissemination by Higher Education Institutes during the Republic of China Era
}

\author{
Guolong Zhao ${ }^{1}$ \\ Teacher Education College of XinYang Normal University
}

\begin{abstract}
During the three decades of the Republic of China, even under constant political turbulences, higher education was not interrupted and instead achieved unprecedented progress, in the area of western literature teaching. Beijing University, Tsinghua University, and National Southwestern Associated University cultivated a generation of influential scholars and experts in western literature education. To understand the influence of English literature education and dissemination of English literature works on the Chinese modern literature, this paper reviews the English literature education activities at famous universities in the era of the Republic of China. The results show that Yenching University offered bilingual courses to enhance students' interests in language and literature in a conductive learning environment. Tsinghua University, aiming to cultivate "scholars of profound knowledge", set up language and literature courses, and improved student's capacity of language and English literature research under proper guidance of faculty. National Southwestern Associated University, integrated by Beijing University, Tsinghua University, and Private Nankai University, offered diversified teaching methods in English literature. Dissemination of English literature works by faculty and graduates at the Republic of China era has contributed to the development of literature translation and theoretic research back then.
\end{abstract}

\section{Keywords}

Education • English literature • Dissemination • Teaching

\footnotetext{
* Key projects of teacher education curriculum reform of Henan Provincial Education Department in 2018: Exploration on the construction and teaching reform of comprehensive activity curriculum group of primary school education based on practical ability, Project Number: 2018-JSJYZD-017

${ }^{1}$ Correspondence to: Guolong Zhao (MA), Teacher Education College of XinYang Normal University, Xinyang 46400.China. Email: zgl5127@xynu.edu.cn
}

Citation: Zhao G. L., Research on English Literature Education Practice and Dissemination by Higher Education Institutes during the Republic of China Era. Educational Sciences: Theory \& Practice, 18(5), 1577-1583. http://dx.doi.org/10.12738/estp.2018.5.055 
During the three decades after establishment of Republic of China in January 1912 when Sun Yat-Sen took the oath in Nanjing and before the establishment of People's Republic of China in 1949, even under constant political turbulences, teaching activities in higher education institutes managed to achieve outstanding outcomes (Zakai, 2015). Particularly in that period, students were passionate about English language study, and China witnessed the emerging of a group of outstanding language experts (Johansen et al., 2014). It has contributed to the wide spreading of English literature in China.

This paper studies the practices of English literature education at Yenching University, Tsinghua University and National Southwestern Associated University, and discusses how their teaching methods had affected the spreading of English literature in China.

\section{English Literature Education Practices}

\section{Yenching University}

Yenching University was established in 1919 by the US church in Beijing, and closed by the Japanese invaders after the outbreak of the Pacific War. In 1942, the university resumed class in Chengdu temporarily, and reopened in Beijing after the outbreak of war against Japan. In 1951, Yenching University was integrated into Beijing University and other universities. The School of Western Languages of Yenching University was first established in 1923. The history of development for the school was closely aligned with the university's development, meaning it also went through stages of opening, development, shutting-down in Beijing, class resumption in Chengdu, and reopening in Beijing. Since the inception of Yenching University, all of its programs were taught in two languages. The university also offered a favoring environment for students to learn languages (Lanktree et al., 2016). The university also had strict examination and reviewing standards to ensure teaching quality, and faculty would tailor teaching approaches to meet students' needs.

The faculty teams of the school, subject to influence of political environment, were unstable. In the first place, the missionaries made up most of the faculty team. As it went along, Chinese faculty increased and accounted for one third of the faculty, and foreign teachers for two thirds. The Chinese teachers were proficient in bilingual teaching, and were highly knowledgeable in their areas, with representatives such as Xie Bingxin and Li Ruqi. Foreign faculty members, include Grace M. Boynton, Ke Anxi, and Bu Duoma. With good teacherstudent relations in place, well-designed curriculum, favorable English-learning environment, Yenching University cultivated a number of foreign language experts in thirty years, such as Xiao Qian, Hu Shiping, Huang Hua, and Wu Weiran. The university has played a role that cannot be overstated for China's education and enlightenment.

\section{Tsinghua University}

Tsinghua University set up Department of Western Literature in 1926, and renamed it to Department of Foreign Languages in 1928. Its goal was to cultivate "scholars of profound knowledge". The university designed 
curriculum in line with the teaching goal, including language courses and literature courses. Language courses are offered in languages of English, Japanese, and French. English was a compulsory course for 4 years, and the others were electives at least for 2 years. The literature courses included literature history (such as Contemporary European Literature) and literary genre (such as Western Novels).

In 1928, the department had 19 teachers. In 1932, faculty size increased to about 23, among them, half were foreign teachers. Most of the Chinese teachers were graduates of Tsinghua University who had received postgraduate education with overseas universities, such as Lou Guanglai, Zhang Jiemin, Chen Futian, and Ye Gongchao. Foreign teachers included Prof. Robert Winter. Tsinghua University had graduated a number of outstanding talents dedicated to literature and research, such as Cao Yu, Qian Zhongshu and Ji Xianlin.

\section{Peking University}

To train the foreign language translators, Qing government established the special-purpose foreign language school in 1862, School of Combined Learning. In 1902, the school was merged into the Imperial University of Peking, and renamed to Translation School in 1903. It offered courses in English, French, Russian and other languages, and in the same year, it set up the department of English literature. In 1912, Imperial University of Peking was renamed to Beijing University. In 1919, Hu Shi headed the English Department of Beijing University. Famous scholars teaching at the department included Lin Yutang, Yu Dafu, and Wang Wenxian. In 1932, the English, French and German departments were merged into the Department of Western Literature, and then into the Department of Foreign Literature. The main courses taught included English thesis, and modern plays.

Table. 1

English Curriculum for Southwestern Associated University

\begin{tabular}{lllc}
\hline Grade & \multicolumn{1}{c}{ Compulsory Courses } & \multicolumn{1}{c}{$\begin{array}{c}\text { Elective } \\
\text { curriculum }\end{array}$} & Credit \\
\hline Freshman & $\begin{array}{l}\text { Common compulsory courses for grammar } \\
\text { schools. }\end{array}$ & 36 \\
\hline Sophomore & $\begin{array}{l}\text { Common compulsory courses for grammar } \\
\text { schools, Professional required course, English } \\
\text { essays and compositions, English Poetry, et al. }\end{array}$ & $\begin{array}{l}\text { History of English } \\
\text { Literature }\end{array}$ & 40 \\
\hline Junior & $\begin{array}{l}\text { Western Novels, Western Drama, second foreign } \\
\text { language, } \text { et al. },\end{array}$ & 34 \\
\hline Senior & $\begin{array}{l}\text { Shakespeare, English essays and compositions, } \\
\text { Dissertation, } \text { et al., }\end{array}$ & 28 \\
\hline
\end{tabular}

\section{National Southwestern Associated University}

In 1936, after the outbreak of the war against Japan, Beijing University, Tsinghua University and Nankai University merged into an associated university, first based in Changsha, and then moved to Kunming. After the war ended, the National Southwestern Associated University declared closing in 1946 and the three universities were resumed. Though at a time of turbulences, English literature teaching at the university was quite active (Mathijs \& Mosselmans, 2000). In terms of curriculum, the National Southwestern Associated 
University inherited the curriculums of foreign language departments at Tsinghua University, Beijing University and Nankai University and made some adjustments on its own due to the political state. The courses included compulsory and elective courses (see details in Table 1). National Southwestern Associated University enjoyed exceptional faculty strength, including Prof. Winter, Qian Zhongshu, Ye Gongchao, and Bian Zhilin. During the operation of the university, it provided a number of much-needed talents for China. Though faced with tough conditions at war times, faculty and students had maintained pure and close relationship, making it a nonnegligible chapter in the history of education in China.

\section{Faculty and Their Contribution to English Literature}

\section{Chinese Faculty}

Wu Mi. In 1921, Wu Mi graduated from Harvard University and started to teach foreign language at Southeast China University in Nanjing. In 1925, he was appointed by Tsinghua University as head of Chinese literature research. After completion of research project, he took the job at Tsinghua University on English literature teaching. Using English language and European literature as the base, Wu referred to the curriculum at Harvard University and set up courses in literature history, such as Ancient Greek Literature and Modern European Literature, courses in literary genre such as Literature Critics and Western Play, and courses by author, such as Shakespeare and Goethe. He also offered the first lecture on comparative literature, "On Comparing Chinese and Western Poetry" (Codde, 2003). After the war against Japan started, he taught at the western language department at the National Southwestern Associated University on topics such as world literary history and new humanism. He was a rigorous scholar, and a great teacher to many outstanding scholars in China.

Ye Gongchao. Ye Gongchao was born to a literary family. He studied in the UK and the USA. At an age of 23, he graduated from Cambridge and returned to teach at Beijing University, as the youngest professor China had then. He taught the courses Modern Poetry in the UK and USA, and Literature Theory. In 1934, he published the Poetry of T.S. Elliot, which was of great significance to the study of Elliot (Morgan, 1974). It is fair to say that Ye was the first in China to research on Elliot. He was extremely talented and knowledgeable with an easygoing interpersonal style with students. His students included Qian Zhongshu and Ji Xianlin.

\section{Foreign Faculty}

I.A. Richards. I.A. Richards, author of the Principles of Literary Criticism, visited China in 1929. During the period 1929 to 1932 , he offered the courses on "literary criticism" and "comparative literature" as a visiting professor at Tsinghua University. Back then, there had already been a great amount of discussions on him and his work in China. Right after he left Beijing, Chinese graduates discussed his critics theory in the graduation thesis. Richards had even deeper research on Elliot's works. He used Elliot's The Waste Land to inspire the readers, and to some extent, promoted introduction and research on the poem. He is known as an envoy between the eastern and western cultures.

William Empson. In 1937, British scholar William Empson, student of I.A. Richards, came to China to teach at Beijing University. After the July $7^{\text {th }}$ Incident of 1937, Empson and Mr. \& Mr.s Richards travelled to 
the southern part of China and joined the National Southwestern Associated University in Changsha. As a sharp modern poet, his courses were informative and enriched. He was known as being especially good at discovering the philosophy between the lines (Baltussen, 2009.). Under his influence, Elliot and Auden became emerging interests of study, replacing romanticism. When he was teaching in China, he played a big role promoting the criticism advocated by I.A. Richards. He left China for Britain in 1952.

Harnold Acton. Harnold Acton, born in Italy, was a famous poet and writer (Bodner, 2008). In 1932, with a huge obsession in the Chinese culture, Acton came to China to teach English literature at Beijing University, his topics including Shelley's Poetry and Shakespeare's Play. He was a very popular professor for giving fun and informative course in English and Chinese (Kahn, Collinge \& Soltysik, 2016). The Collection of Modern Chinese Poetry of 1936, jointly translated by Acton and Chen Shixiang, was the first work to introduce Chinese new poetry to the rest of the world.

\section{English Literature and Its Effect}

\section{Translations}

During the Republic of China era, more than 700 English literature works were translated. Over 500 translations were published in the 1930s and 1940s. Famous translators include: Bian Zhili, Liang Shiqiu, and Qian Gechuan. Their translation covers genre of poetry, novel, and memoires.

Table 2

Translators and their Works

\begin{tabular}{ll}
\hline Translator & \multicolumn{1}{c}{ Translation works } \\
\hline \multirow{2}{*}{ Jiaxun Pan } & $\begin{array}{l}\text { Mrs. van der Mel's fan (1926), The career of Mrs. Warren (1923), Selected plays by } \\
\text { Bernard Shaw (1956), Selected Plays of Ibsen (1921), Four kinds of Ibsen's plays } \\
\text { (1959), A doll's house (1963). }\end{array}$ \\
Xianyi Yang & $\begin{array}{l}\text { Birds, peace, The Odysey, Pastoral, Kaiser and Cleopatra, Unlucky abode, Flower } \\
\text { girl, Modern British Poetry notes. }\end{array}$ \\
Zhilin Bian & $\begin{array}{l}\text { Midsummer night's dream, Queen Victoria turn, adolphe, Counterfeit maker, Narrow } \\
\text { gate, English poetry with twelve French Poems, Western window set. } \\
\text { Guruo zhang }\end{array}$ Return to the country, Tess of the downer.
\end{tabular}

\section{Research Publication}

Main publications are listed in Table 3:

Table 3

Litterateur and their Works

\begin{tabular}{ll}
\hline Author & \multicolumn{1}{c}{ Works } \\
\hline Yuxiu Sun & $\begin{array}{l}\text { European and American Novels, British novelist in the seventeenth Century, Two } \\
\text { criticisms of Goethe and Dickens. The origin of British drama. Marlow's operas. }\end{array}$ \\
Shakespeare's operas.
\end{tabular}




\section{Gradates' Contribution}

The department of foreign languages of the National Southwestern Associated University gradated 220 students in total. When three universities were resumed, over 140 students continued their study at Beijing University or Tsinghua University. Most of them had career as researchers, educators, and writers (Ramchandani \& Iles, 2014). For example, Liu Henian, Wang Zuoliang, and Xu Guozhang taught at universities, Jiang Guinong, Zhang Wanying worked for diplomatic missions and news agencies, and Wang Jinzhong and Hsu Kai-yu worked as educators and researchers overseas. These scholars have made significant contributions to compilation of textbooks, translation of literature, and wide-spreading English literatures in China (Lockwood \& Viding, 2016).

\section{Conclusion}

This paper reviews the history of English literature education and spreading of English literature in China during the Republic of China era, and studies the effect of English literature education and spreading of literature on China's modern literature. Following are the conclusions:

1. Yenching University, Beijing University, Tsinghua University and National Southwestern Associated University all offered well-designed English courses. Teachers valued student's initiatives and motivate their interests in learning. A great number of outstanding scholars were cultivated.

2. During the Republic of China era, contribution from teachers and graduates in spreading English literature has promoted development of literature translation, and art theory research in China.

\section{References}

Baltussen, H. (2009). Personal grief and public mourning in Plutarch's consolation to his wife. American Journal of Philology, 130(1), 67-98. http://dx.doi. org/10.1353/ajp.0.0044

Bodner, K. (2008). Mouse trap: a text-critical problem with rodents in the ark narrative. Journal of Theological Studies, 59(2), 634-649.

Braithwaite, J., Westbrook, M. T., Iedema, R., Mallock, N. A., Forsyth, R., \& Zhang, K. (2013). A tale of two cultures: bringing literary analysis and computational linguistics together. Social Science \& Medicine, 60(5), 1149-62.

Codde, P. (2003). Polysystem theory revisited: a new comparative introduction. Poetics Today, 24(1), 91-126. http://dx.doi. org/10.1215/03335372-24-1-91

Johansen, C. T., Joseph B Dubé, Loyzer, M. N., Macdonald, A., Carter, D. E., \& Mcintyre, A. D. (2014). Lipidseq: a next-generation clinical resequencing panel for monogenic dyslipidemias. Journal of Lipid Research, 55(4), 765. http://dx.doi. org/10.1194/jlr.D045963 
Kahn, J. R., Collinge, W., \& Soltysik, R. (2016). Post-9/11 veterans and their partners improve mental health outcomes with a self-directed mobile and web-based wellness training program: a randomized controlled trial. Journal of Medical Internet Research, 18(9), 255.

Lanktree, M. B., Lanktree, B. B., Guillaume Paré, Waye, J. S., Sadikovic, B., \& Crowther, M. A. (2016). Examining the clinical use of hemochromatosis genetic testing. Canadian Journal of Gastroenterology \& Hepatology, 29(1), 41. http://dx.doi. org/10.1155/2015/941406

L. Lockwood, P., \& Viding, E. (2016). Commentary: Conduct disorder and perceiving harm to others-a reflection on Michalska et al.(2016). Journal of child psychology and psychiatry, 57(4), 520-522.

Mathijs, E., \& Mosselmans, B. (2000). Mimesis and the representation of reality: a historical world view. Foundations of Science, 5(1), 61-102.

Morgan, W. W. (1974). Form, tradition, and consolation in hardy's "poems of 1912-13". Pmla, 89(3), 496-505.

Ramchandani, P., \& Iles, J. (2014). Commentary: getting fathers into parenting programmes--a reflection on panter-brick et al. (2014). J Child Psychol Psychiatry, 55(11), 1213-1214.

Spicer, P. (2007). Commentary: from fathering to parenting and back again. Applied Developmental Science, 11(4), 203-204. http://dx.doi. org/ 10.1080/10888690701762084

Walsh, T. B., Dayton, C. J., Erwin, M. S., Muzik, M., Busuito, A., \& Rosenblum, K. L. (2014). Fathering after military deployment: parenting challenges and goals of fathers of young children. Health Soc Work, 39(1), 35-44. http://dx.doi. org/10.1093/hsw/hlu005

Zakai, A. (2015). Constructing and representing reality: Hegel and the making of Erich Auerbach's mimesis. Digital Philology A Journal of Medieval Cultures, 4(1), 106-133. 